УДК 636.7:636.8:619:616-07:619:616.36

(C) 2014

\author{
Локес П. І., кандидат ветеринарних наук \\ Полтавська державна аграрна академія
}

Локес-Крупка Т. П., аспірант

(науковий керівник - доктор біологічних наук, професор, академік НААН М. І. Цвіліховський) Національний Університет біоресурсів і природокористування України

\title{
ДИФЕРЕНЦІЙНА ДІАГНОСТИКА ХВОРОБ ПЕЧІНКИ У СВІЙСЬКИХ СОБАК І КОТІВ
}

\section{Рецензент - доктор ветеринарних наук, професор Б. П. Киричко}

Встановлено, щзо патологія печінки має значне поширення серед свійських собак та котів. Наведена структура захворюваності печінки у тварин даних видів.Встановлено, щзо диференціацію найпоширеніиих хвороб печінки (гепатиту, гепатодистрофії та цирозу) в собак $і$ котів необхідно проводити за клінічними ознаками, симптомами, результатами УЗД $i$ лабораторного аналізу крові. Описані найтиповіші симптоми захворювань, ̈̈х ультрасонографічні відмінності та характерні біохімічні показники крові.

Ключові слова: коти, собаки, хвороби печінки, гепатит, гепатодистрофія, ичироз, методи діагностики.

Постановка проблеми. Завдяки досвіду, накопиченому науковцями впродовж багатьох років, і розвитку сучасних високих технологій значно легшим стало розпізнавання внутрішніх хвороб і поглибилося розуміння багатьох питань патогенезу. Безперервно зростає кількість інструментальних, біохімічних і біофізичних методів дослідження. Не зважаючи на значну кількість допоміжних методів досліджень, практикуючий лікар ветеринарної медицини, як і раніше, має значні труднощі у вирішенні загальних діагностичних проблем.

Головні труднощі діагностики полягають у тому, що багато внутрішніх хвороб не мають патогномонічних симптомів та ознак: одне і те ж захворювання може характеризуватися тими або іншими ознаками, а одні й ті ж симптоми та ознаки зустрічаються при багатьох хворобах.

Не дивлячись на все вищезазначене, розпізнавання захворювань та їх диференційна діагностика потребують подальшого вивчення. Передусім це стосується патології печінки.

Аналіз основних досліджень і публікацій, у яких започатковано розв'язання проблеми. Патологія печінки має значне поширення серед дрібних домашніх тварин. У структурі внутрішніх хвороб, за даними різних авторів, патологія печінки становить від 5 до 50,8 \% [1-5, 9, 14-15, 17-18]. Діагностують гепатит, гепатодистрофію, цироз, абсцеси печінки, холецистит і жовчнокам'яну хворобу $[14-15,17-18]$. За даними J. H. Poldervaart [16], структура хвороб печінки в собак наступна: гепатит складає $18 \%$, метастазуючі пухлини - 13,9; застій крові - 9,1; портосистемні шунти - 5,7; кістоз печінки - 5,6; фіброз - 4,1; ліпідоз - 3,9; первинні пухлини $-3,8$; цироз - 2,3; інші хвороби печінки - 33,6 \%.

За результатами лабораторних досліджень, гепатодистрофія діагностована у 50,8 \% собак службових порід $[5,6]$, за іншими даними - 30$40 \%$, а цироз печінки - у $34,7 \%$ [10-13].

Не дивлячись на значні успіхи у вивченні хвороб печінки, у ветеринарній медицині немає загальноприйнятої схеми диференційної діагностики для тварин різних видів, зокрема для собак і котів.

Мета роботи: розробка інформативних методів диференційної діагностики хвороби печінки у свійських собак та котів.

Завдання дослідження: визначити диференційну цінність клінічних, ультрасонографічних, морфологічних та біохімічних показників крові у диференційній діагностиці патологій печінки у свійських собак і котів.

Матеріал і методи дослідження. Дослідження проводили на 77 свійських котах різного віку, статі та порід із застосуванням основних лабораторних, інструментальних та морфологічних методів. У 10 тварин реєстрували гепатит, 12 - гепатодистрофію (з них 8 випадків гепатоліпідозу), 25 - холецистит; 30 тварин (без видимих ознак патології) становили контрольну групу.

Проведено дослідження 195 собак, з яких 50 тварин були клінічно здоровими (контрольна група), у 22 собак під час клінічного обстеження діагностували гепатит, у 66 - гепатодистрофію, у 12 - цироз і в 45 - запалення жовчного міхура.

Дослідження крові проводили за уніфіковани- 


\section{ВЕТЕРИНАРНА МЕДИЦИНА}

ми методами, наведеними у довідниках із клінічної біохімії та керівництвах 3 лабораторної справи $[6,8]$.

Матеріали досліджень оброблено методами варіаційної статистики.

Результати досліджень. Диференціацію найбільш поширених хвороб печінки (гепатиту, гепатодистрофіï та цирозу) в собак і котів необхідно проводити за клінічними симптомами, результатами УЗД та лабораторного аналізу крові.

За патології печінки (гепатит, гепатодистрофія та цироз) у всіх собак типовим симптомом $\epsilon$ пригнічення (100,0 \%), у котів пригнічення спостерігається за гепатиту - у 100,0 \%, а за гепатодистрофіï - у 66,7 \% тварин.

Лихоманка характерна за гепатиту для 86,4 \% собак і 100,0 \% котів. За гепатодистрофії підвищення загальної температури тіла спостерігали у $16,7 \%$ собак та 25,0 \% котів. За цирозу температура тіла коливалася у фізіологічних межах. Тобто, лихоманка була характерна для гострого запального процесу печінки. Продукти інтоксикації створювали гальмівну дію на центр апетиту, що клінічно проявлялося ано- та гіпорексією. Ця ознака притаманна тваринам за гепатиту (100,0 \% собак та котів), тоді як за інших гепатопатій вона була менш вираженою. В міру згасання запалення та хронізації патологічного процесу зменшувалася больова реакція у процесі пальпації печінки. Одним із проявів синдрому холестазу була жовтяниця, ознаки якої реєстрували у 50,0\% хворих собак та 90,0\% котів за гепатиту; 16,7 \% i 75,0\% - за гепатодистрофії відповідно, та 25,0 \% собак - за цирозу печінки. Отже, для котів розвиток жовтяниці більш характерний.

Патологія печінки супроводжувалася гепато- i спленомегалією, що зумовлено тісним взаємозв'язком ретикулогістіоцитарного апарату цих органів, кровопостачанням системи ворітної вени, лімфодинамікою та інервацією. Врешті-решт порушення гемодинаміки в портальному руслі призводило до застійної гіперемії органів черевної порожнини 3 подальшим розвитком асциту (75,0 \% за цирозу), що є важливим диференціально діагностичним і прогностичним симптомом патології у собак.

Таким чином, у собак $є$ кілька симптомів, за якими можна диференціювати хвороби печінки: гепатит, гепатодистрофію і цироз. Передусім, це температура тіла: лихоманку виявляли у 86,4 \% собак за гепатиту й лише у 16,7 \% (субфебрильна) за гепатодистрофії. За цирозу печінки температура тіла в нормі. Другий важливий симптом для диференціації - асцит, який діагностують лише за цирозу печінки. Типовим симптомом для цього захворювання $\epsilon$ виснаження. Болючість у ділянці печінки найбільш характерна для гепатиту (100,0 \%) і гепатодистрофії (89,4\%), а гепатомегалія - для гепатодистрофії. Однак ці два захворювання диференціюють за температурою тіла, блюванням (за гепатиту - у 63,6 \% собак), полідипсією (100,0 \%) та результатами дослідження лейкограми (за гепатиту нейтрофілія 3 регенеративним зрушенням ядра).

У котів гепатит і гепатодистрофію диференціюють за результатами термометрії та виведення лейкограми (нейтрофілія типова для гепатиту). Інші симптоми (пригнічення, ано- або гіпорексія, болючість у ділянці печінки, гепатомегалія, жовтяниця) важливі для діагностування обох патологій, але диференціювати хвороби печінки виключно за ними неможливо.

Клінічно диференціювати холецистит досить непросто, оскільки симптоми не характерні. Найкращий діагностичний критерій - ультрасонографічні ознаки: потовщення стінки жовчного міхура, підвищення ехогенності жовчі та прилеглих тканин печінки.

Найбільш показові відмінності ехограми печінки за УЗД у собак та котів наступні: за гепатиту - гепатомегалія, потовщення капсули за рівних контурів органа, зниження ехогенності паренхіми, ехогенна фрагментація іiі структури. На відміну від гепатиту, за гепатодистрофії найбільш виражені наступні зміни ехограми: збільшення ехогенності паренхіми, заокруглення країв печінки та щільна ехоструктура капсули.

За цирозу печінки в собак характерне рівномірне ущільнення паренхіми, тоді як за гепатиту легко визначається заокруглення країв часток печінки. Крім того, за гепатиту і гепатозу не відбувається накопичення асцитичної рідини в черевній порожнині.

Отже, найкраще гепатит i гепатодистрофію диференціювати за вищеперерахованими симптомами, а для цирозу найбільш характерним симптомом, який відрізняє його від гепатиту i гепатозу, є асцит.

Дані сонографії завжди слід доповнювати результатами клініко-лабораторних досліджень.

Аналіз показників еритроцитопоезу не має значення в диференційній діагностиці; враховувати необхідно лише результати підрахунку лейкоцитів і виведення лейкограми. За гострого перебігу гепатиту у 100,0 \% собак виражена нейтрофілія 3 регенеративним зрушенням ядра. За гепатодистрофії та цирозу печінки зміни лейкограми невірогідні.

Для диференціації гепатиту і гепатодистрофії 


\section{ВЕТЕРИНАРНА МЕДИЦИНА}

показовими були окремі результати біохімічного дослідження крові (табл. 1). У 95,5 \% собак за гепатиту вищий рівень загального білірубіну (10,6-25,6 мкмоль/л), ніж у хворих на гепатодистрофію $(5,1-12,5)$, у 54,6 \% - кон'югованого білірубіну, у 63,6 \% вищі показники АлАТ і 77,3 \% - тимолової проби. І все ж у хворих собак не було жодного біохімічного показника, за яким можна було б зі 100 \% інформативністю відрізнити гепатит і гепатодистрофію.

Тому необхідно враховувати результати клінічного та ультразвукового дослідження (за гепатиту зниження ехогенності паренхіми, за гепатодистрофії - збільшення) і виведення лейкограми (за гепатиту паличкоядерних нейтрофілів 12,0$21,0 \% ; 17,0 \pm 0,69$; за гепатодистрофії - 2-5\%; $3,5 \pm 0,21)$.

За цирозу печінки у собак авторами не відмічено біохімічних показників, які б відрізнялися від аналогічних за гепатиту і гепатодистрофії (табл. 1).

Уміст загального білку, альбумінів, активність амінотрансфераз були в межах, характерних для гепатодистрофії, а рівень білірубіну знаходився в тих же межах, що й за гепатиту. Найбільш інформативним тестом для цирозу печінки є визначення ХCT, рівень яких збільшується у тварин, хворих на цироз, а за гепатодистрофії, за даними літератури, він, навпаки, зменшується [7].

У результаті досліджень встановлено, що у $100,0 \%$ собак за цирозу печінки зростав вміст ХСТ і становив 0,285-0,457 г/л (табл. 1). Отже, за диференціації цирозу необхідно більше уваги звертати на симптоми (асцит), результати УЗД та рівень ХСТ.

Ширший і виразніший діапазон показників у котів: стовідсоткову диференціальну інформативність має визначення загальноприйнятих показників функціонального стану печінки (табл. 2).

Так, за гепатиту вміст загального білірубіну знаходився в межах 31,0-121,4 мкмоль/л, а за гепатодистрофії - 8,2-11,8, кон'югованого білірубіну, відповідно, 8,3-22,1 і 2,5-3,6 мкмоль/л.

\section{1. Розбіжсність біохімічних показників крові собак за гепатиту, гепатодистрофії та цирозу печінки}

\begin{tabular}{|c|c|c|c|c|c|c|}
\hline Показник & Гепатит & $\begin{array}{c}\text { Гепато- } \\
\text { дистрофія }\end{array}$ & $\begin{array}{c}\text { Зміни, \% } \\
\text { (гепатит/ } \\
\text { гепатодис- } \\
\text { трофія) }\end{array}$ & $\begin{array}{c}\text { Цироз } \\
\text { печінки }\end{array}$ & $\begin{array}{c}\text { 3міни, \% } \\
\text { (гепатит/ } \\
\text { цироз) }\end{array}$ & $\begin{array}{c}\text { 3міни, \% } \\
\text { (гепатодистро- } \\
\text { фія/цироз) }\end{array}$ \\
\hline $\begin{array}{c}\text { Загальний білі- } \\
\text { рубін, мкмоль/л }\end{array}$ & $10,6-25,6$ & $5,1-12,5$ & $\uparrow 95,5$ & $9,5-17,9$ & $\uparrow 75$ & $\downarrow 33,3$ \\
\hline $\begin{array}{c}\text { Кон'югован. } \\
\text { білірубін, } \\
\text { мкмоль/л }\end{array}$ & $3,7-12,2$ & $2,8-9,9$ & $\uparrow 54,6$ & - & - & - \\
\hline АлАТ, Од/л & $73,0-$ & $63,8-95,8$ & $\uparrow 63,6$ & $\begin{array}{c}43,5- \\
116,3\end{array}$ & $\uparrow 58,3$ & $\downarrow 41,7$ \\
\hline АсАТ, Од/л & $50,0-$ & $84,7-$ & $\uparrow 18,2$ & $66,8-$ & - & $\downarrow 33,3$ \\
\hline $\begin{array}{c}\text { Тимолова } \\
\text { проба, Од. SН }\end{array}$ & $1,7-2,7$ & $1,3-1,8$ & $\uparrow 77,3$ & - & - & - \\
\hline ЛФ, Од. Бод. & $6,7-17,0$ & $5,4-14,1$ & $\uparrow 26,9$ & $4,6-14,8$ & $\uparrow 22,7$ & $\downarrow 8,3$ \\
\hline
\end{tabular}

\section{2. Розбіжність біохімічних показників крові котів за гепатиту і гепатодистрофії}

\begin{tabular}{|c|c|c|c|}
\hline Показник & Гепатит & Гепатодистрофія & Зміни, \% \\
\hline $\begin{array}{c}\text { Загальний білірубін, } \\
\text { мкмоль/л }\end{array}$ & $31,0-121,4$ & $8,2-11,8$ & $\uparrow 100$ \\
\hline $\begin{array}{c}\text { Кон’югований білірубін, } \\
\text { мкмоль/л }\end{array}$ & $8,3-22,1$ & $2,5-3,6$ & $\uparrow 100$ \\
\hline АлАТ, Од/л & $210,2-282,4$ & $121,2-157,8$ & $\uparrow 100$ \\
\hline АсАТ, Од/л & $164,6-215,4$ & $122,9-153,7$ & $\uparrow 100$ \\
\hline ЛФ, Од. Бод. & $9,5-20,8$ & $5,0-7,6$ & $\uparrow 100$ \\
\hline Холестерол, моль/л & $1,9-2,8$ & $2,6-4,7$ & $\downarrow 83,3$ \\
\hline
\end{tabular}




\section{ВЕТЕРИНАРНА МЕДИЦИНА}

Значно вища за гепатиту була активність амінотрансфераз, лужної фосфатази i, навпаки, менший уміст холестеролу.

Найбільш типовим показником диференційної діагностики холециститу був уміст білірубіну, рівень якого перевищує показник за гепатиту у

\section{БІБЛІОГРАФІЯ}

1. Багаутдинов А. М. Морфологические изменения у свиней при гепатозе и после введения сантохина / А. М. Багаутдинов // Ветеринария. 2008. - C. 40-41.

2. Влізло В. В. Жировий гепатоз у високопродуктивних корів : автореф. дис. ... доктора вет. наук : спец. 16.00.01 «Діагностика і терапія тварин» / В. В. Влізло. - К., 1998. - 34 с.

3. Влізло В. В. Експериментальне відтворення жирової інфільтрації печінки у високопродуктивних корів / В. В. Влізло // Вісник Білоцерків. держ. аграр. ун-ту. - Біла Церква, 1998. - Вип. 4. - Ч. 1. C. 14-17.

4. Дикий O. А. Гепатодистрофія у собак службових порід (етіологія, патогенез, лікування та профілактика) : автореф. дис. ... канд. вет. наук : спец. 16.00.01 «Діагностика і терапія тварин»/ О. А. Дикий. - Біла Церква, 2000. - 17 с.

5. Інформативність окремих показників для діагностики патології печінки i нирок у собак / О. А. Дикий, В. І. Головаха, В. П. Фасоля [та ін.] // Вісник Білоцерків. держ. аграр. ун-ту. - Біла Церква, 2000. - Вип. 11. - С. 32-37.

6. Камышников В. С. Справочник по клиникобиохимической лабораторной диагностике: В 2 т. / В. С. Камышников. - Минск : Беларусь, 2000.T. 2. -463 c.

7. Кібкало Д. В. Інформативність біохімічних показників сполучної тканини в диференційній діагностиці гепатодистрофії і цирозу печінки у корів : автореф. дис. ... канд. вет. наук : спец. 16.00.01 «Діагностика i терапія тварин» / Д. В. Кібкало. - Біла Церква, 2004. - 20 с.

8. Клиническая лабораторная диагностика в ветеринарии: Справочное издание / И. П. Кондрахин, Н. В. Курилов, А. Г. Малахов [и др.]. М. : Агропромиздат, 1985. - 287 c.

9. Рекомендации по диагностике, лечению и профилактике токсических поражений печени у молодняка свиней / А. В. Сенько, А. П. Курдеко,
100,0 \% хворих собак.

Висновок. Таким чином, проведення комплексного обстеження, з урахуванням результатів клінічних досліджень, УЗД та змін показників крові, дає змогу проводити диференційну діагностику гепатопатологій у собак та котів.

В. А. Телепнев [и др.]. - Витебск, 2001. - 33 с.

10. Соловйова Л. М. Порівняльна оцінка методів діагностики і терапії гепатодистрофії у собак : автореф. дис. ... канд. вет. наук : спец. 16.00.01 «Діагностика і терапія тварин» / Л. М. Соловйова. - Біла Церква, 2004. - 21 с.

11. Фасоля В. П. Структура хвороб собак у м. Житомирі (повідомлення 1) / В. П. Фасоля // Вісник Білоцерків. держ. аграр. ун-ту. - Біла Церква, 2001. - Вип. 16. - С. 215-219.

12. Фасоля В. П. Структура внутрішніх хвороб собак у м. Житомирі (повідомлення 2) / В. П. Фасоля // Вісник Білоцерків. держ. аграр. ун-ту. Біла Церква, 2001. - Вип. 18. - С. 158-163.

13. Фасоля В. П. Диспансеризація собак службових порід : автореф. дис. ... доктора вет. наук : спец. 16.00.01 «Діагностика і терапія тварин»/ В. П. Фасоля. - Біла Церква, 2008. - 38 с.

14. Cuccovillo A. Cellular features of sonographic target lesions of the liver and spleen in $21 \mathrm{dogs}$ and a cat / A. Cuccovillo, C. R. Lamb // Vet. Radiol. Ultrasound. - 2002. - Vol. 43 (3). - P. 275-278.

15. Hepatitis with special reference to dogs. A review on the pathogenesis and infectious etiologies, including unpublished results of recent own studies / [S. Y. Boomkens, L. C. Penning, H. F. Egberink [et al.] // Vet. Q. - 2004. Vol. 26 (3). - P. 107-114.

16. Primary hepatitis in dogs: a retrospective review (2002-2006) / [J. H. Poldervaart, R. P. Favier, L. C. Penning et al.] // J. Vet. Intern. Med. - 2009. Vol. 23 (1). - P. 72-80.

17. Rothuizen J. T. S. Hepatitis in dogs; a review / J. T. S. Rothuizen // Tijdschr Diergeneeskd. - 1998. - Vol. 123 (8). - P. 246-252.

18. Weiss D.J. Inflammatory liver disease / D. J. Weiss, P. J. Armstrong, J. Gagne // Semin. Vet. Med. Surg. (Small Anim.). - 1997. - Vol. 12 (1). - P. 22-27. 